\author{
John Fredy Gil Bonilla \\ Complutense University of Madrid, Spain
}

\title{
MULTIMODAL METAPHORS AND ADVERTISING: A CROSS-CULTURAL COMPARISON OF THE USE OF BEHAVIOURAL MULTIMODAL METAPHORS
}

Summary. The main purpose of this paper is to analyze how culture is embedded in the way viewers from different language backgrounds conceptualize and interpret the same multimodal metaphors. Therefore, interaction between metaphor and culture is hence a crucial aspect of research in this study. Following Lakoff and Johnson's (1980) and Forceville's $(1996,2009)$ approaches, this paper examines how a comparative study undertaken from a cross-cultural perspective can shed light on how culture is an influential factor that can trigger changes in interpretations and reactions in the viewers. Data for this research were gathered with the help of 240 participants taken from 8 different language backgrounds. The subjects of this study were supplied with a questionnaire which consisted of three multimodal metaphors and 8 questions. In particular, I want to focus on the following research questions: (1) Which figurative B-term do different cultures conceptualize in a multimodal metaphor? (2) How aggressive are these multimodal metaphors considered by the participants of the study? On the basis of the results of this research, it can be concluded that not only the cultural background but also the personal has some influence on the way respondents interpret multimodal metaphors. The reactions identified in the responses of the subjects are influenced by different factors: religion, personal and societal experiences, beliefs, etc.

Keywords: multimodality; metaphors; advertising; cross-cultural differences; figurative-B term.

\section{Introduction}

\section{Background and preview}

In recent years, there has been a growing interest in metaphors, which have become a central part of linguistic studies (see, for instance, Lakoff and Johnson, 1980; Langacker, 1987; Lakoff and Turner, 1989; Croft, 1993; Lakoff, 1993). Although, however, some scholars have lately begun to pay more systematic attention to other verbal tropes, that is, work on visual or pictorial metaphor (see, for example, Carroll, 1994; Dirven, 2009; Forceville, 1994, 1996; Gibbs, 1994), and let alone multimodal metaphors, studies and appropriate theories in this field are still relatively scarce (cf. Forceville and Urios Aparisi, 2009). The aim of the present study is to analyze the culture 
factors that govern the way people of different linguistic backgrounds conceptualize and interpret multimodal metaphors. It should be noted that not only research on multimodal metaphors is still in its infancy, but also not much interest has been paid to the interaction between metaphor and culture (e.g. Gibbs, 1999; Kövecses, 2005).

Many studies have been centred on the vital role that metaphors have in human life and, therefore, regarded as cognitive tools. Lakoff and Johnson (1980, p. 3) argued that metaphors are ubiquitous in human life, thoughts and actions, and that our conceptual system is "fundamentally metaphorical in nature". In other words, metaphor is a cognitive process that allows the mapping from a source domain onto a target domain and this mapping enables language users to produce not only unspoken assumptions and logical relations but also to conceptualize and express experiences. Forceville (2009, Introduction, p. $2^{21}$ ) indicates that the scrutiny of metaphors is a way to obtain a better understanding of how cultures differ in their beliefs and knowledge given that metaphors have a persuasive power in the manner they influence the values and the ways of behaving of the society. The conceptualization of a metaphor is very likely to differ from one viewer to another in terms of that each viewer has distinct interpretations of the same event. That is to say, the mappings from the source to the target domain are culturally determined.

In brief, multimodal advertisements have been selected for this study given that research on this field is still scarce. Moreover, it seems that so far even less attention has been paid to the use of multimodal metaphor in behavioural adverts, namely, adverts which are intended to trigger a behavioural change - in particular to those regarding current issues, such as war, religion and habits.

Therefore, the aim of this paper is to make a comparative study of the use of multimodal metaphors in behavioural advertisements, following metaphor theories and analyses developed by authors such as Lakoff and Johnson (1980) and Forceville (1996, 2009). It is structured in the following way: after the introductory background and preview are presented, Section 1

\footnotetext{
${ }^{21}$ As Forceville's (2009) Online Course on pictorial and multimodal metaphor does not include page numbers, this numbering was added so that citations may be more easily referred to.
} 
further reviews the literature that is relevant to the purposes of the present investigation, and outlines the main hypotheses, aims, research questions and objectives involved. Section 2 introduces the data and methodology employed for the elaboration of this study. Section 3 deals with the analysis of data and the presentation and discussion of the results. And finally, Section 4 examines the main conclusions and implications that may be drawn from the analysis.

\section{Literature review}

Not only does all advertising have the same intention in terms of selling a product, promoting public health and encouraging charity donations, but also it has a psychological purpose in the way it attracts a broad audience with the aim of promoting a product, being moralizing or changing some behaviour in the public. Regarding the adverts in this paper, they have the finality of encouraging the audience not to buy a product but to change their deportment. As Cook (2001) puts forward, the main characteristic of an advertisement is to change the behaviour of the viewers: that change can be to stop smoking, help others, or apply for a job. Advertising of one product can differ from another in the way they reach the audience given that one advert may simultaneously target more than one audience and promote more than one behavioural change. Moreover, Esposito (2011, p. 213) suggests that any analysis of advertisements offers multifarious challenges as they can draw upon various modes at the same time, to convey their messages with the combination of both language and imagery.

This research paper analyzes both how participants of different cultures construe the figurative B-term (source domain) of multimodal metaphors and how aggressive these metaphors are considered by the participants under study. Therefore, not only a comparison between multimodality and monomodality will be presented, but also a review of how culture and metaphors are interwoven. 


\section{Multimodality versus monomodality}

Forceville proposes two terms: a "literal primary subject" and a "figurative secondary subject" (1996, p. 5). In each metaphor, there is a mapping of one or more features from the figurative secondary subject, also known as the figurative B-term (source domain) onto the literal primary subject, also known as the literal A-term (target domain). The difference between multimodal and pictorial metaphors is posed in the sense that in the first the target and source domain belong to different modes. However, the second is considered as monomodal because the target and source pertain to the same mode (Forceville, 2009).

Forceville (1996) provides the explanation of four types of pictorial metaphors and more recently ( 2002a) has proposed a more updated explanation of these four types of pictorial metaphors. Only the fourth type is applied in this study, that is, a verbo-pictorial metaphor which no longer becomes part of the realm of the visual and is better considered as a subtype of a superordinate category, to be labeled "multimodal metaphor" (Forceville, 2008 , p. 464). In other words, what for one person would be a monomodal metaphor of the pictorial variety, would for another be a multimodal metaphor of the pictorial-verbal variety (for more discussion, Bounegru/Forceville 2011).

\section{Culture and metaphors}

George Lakoff and Mark Johnson (1980, p. 57) claim that words are flexible when considering meaning; that is to say, words are not fixed and never precisely explain our physical experiences free from social influences:

Every experience takes place within a vast background of cultural presuppositions. It can be misleading, therefore, to speak of direct physical experience as which we then 'interpret' in terms of our conceptual system. Cultural assumptions, values, and attitudes are not a conceptual overlay which we may or may not place upon experience as we choose. It would be more correct to say that all experience is cultural through and through, that we experience our "world" in such a way that our culture is already present in the very experience itself. 
For them (1980, p. 3), metaphors go beyond language in the sense that they show to a certain degree how people think and interpret concepts in life. In other words, the way we think and understand the world can be considered to some extent as metaphorical. According to them, metaphors are used in society as a way of presenting and displaying our memories and experiences to the world. Lakoff and Johnson (1980) highlight that metaphors are grounded in the interplay of our bodies with the physical and social world. We impose the same structure on aspects of our physical experiences and conceptualize them accordingly. Therefore, such metaphors are not arbitrary. Since they emerge from systematic correlations with our physical and cultural experiences, which both provide many possible bases for metaphorical concepts, metaphors can vary from culture to culture. Internal systematicity, external systematicity, grounding and coherence play also an important role in the variation of metaphors among cultures. Thus, metaphors are crucial for understanding and learning. The previous citation by Lakoff and Johnson (1950, p. 57) suggests that metaphors not only tend to reflect but also influence the values and ways of thinking of different linguistic, social and cultural groups. Viewers from various cultural backgrounds might understand the same metaphor in drastically different manners.

Going beyond this aspect, many other researchers have more recently paid attention to the interaction between culture and metaphor within Cognitive Linguistics (see, for instance, Shore, 1996; Gibbs, 1994, 1999; Kövecses, 2005). According to Gibbs (1994, p. 435), many concepts that fundamentally shape our way of thinking (i.e., causation, time, love and anger) are, at the very least, partly constituted by metaphor. In other words, the way we interpret metaphors may depend on our experiences and cultural background. Even a member of the same community may interpret their surrounding differently from the others. Put differently, Gibb's assumption can be compared to Lakoff and Johnson's in the sense that the latter scholars argue that viewers from distinct cultural backgrounds may have a different conceptualization of the metaphor, while the former goes deeper by asserting that even a member of the same community may have a different perception of reality. Thus, it is not necessary to belong to a completely different culture so as to have a different conceptualization of a metaphor. In this respect, Forceville's assumption that the understanding of culturally embedded knowledge and 
beliefs may highly benefit from the study of multimodal metaphor manifestations (2009; Introduction, p. 2) is relevant in terms of that multimodal metaphors are a good device or instrument to enhance the understanding of culture. Lakoff and Turner (1989, p. 66) argue that knowledge about source domains is not merely a question of embodiment, but also of cultural connotations and correspondences. Numerous details in advertisements could consequently only be thoroughly accessed and appreciated by those viewers who are aware of very specific linguistic and idiomatic phrases, myths and beliefs of a culture or society. Therefore, although theories on a multimodal metaphor are still somewhat in their infancy, this cognitive device has proved to be particularly useful for the analysis of multimodal or cross-cultural discourse and communication, and to be both pervasive and persuasive when used in contemporary advertising.

\section{Aim and hypothesis}

As it seems evident to presume, the advertisements studied would all be very rich in multimodal metaphors. Therefore, it is hypothesized that significant cross-cultural differences may be identified for the targeted audience. The multimodal metaphors provided to the participants would reflect a major difference in their conceptualization. Indeed, in this context, multimodal metaphors are mainly used in order to change some deportment in the respondents. Hence, the multimodal metaphors have a tendency to provoke a behavioural change through the use of negative advertising. That is the reason why the purpose of this study is to see if these metaphors incite negative reactions and are regarded as aggressive, as it seems to be, and if this variation is dependent on the cultural background of each member. Also, the figurative B-term construed by the participants is analyzed in terms of how their interpretations vary from one ad to the other. These last aspects raise the following questions:

1. Which figurative B-term do different cultures conceptualize in a multimodal metaphor?

2. How aggressive are these metaphors considered by the participants under study? 


\section{Methodology}

\section{Data: the sample and the participants}

Table 1 presents the different eight language backgrounds and the total number of participants.

Table 1.

\section{Language backgrounds and number of participants}

\begin{tabular}{|c|c|}
\hline Participants & Number \\
\hline Spanish & 30 \\
\hline Chinese & 30 \\
\hline Turkish & 30 \\
\hline Romanian & 30 \\
\hline English & 30 \\
\hline Arabic & 30 \\
\hline Italian & 30 \\
\hline Polish & 30 \\
\hline
\end{tabular}

The interpretations of the figurative B-terms by the 240 participants in each of the advertisements are presented in Table 2, Table 2.1 and Table 2.2. These tables show the source domains construed in the three advertisements by the participants under study. More specifically, advert $A$ is conceptualized as a bomb / weapon / grenade, germs / bacteria and health and pesticides. Advert $B$ is conceptualized as animal care, children care and neutral, while the figurative B-terms construed in advert $\mathrm{C}$ regard father conditions, children conditions and neutral status. The term neutral refers to those participants who stay impartial or unbiased in terms of showing the same priority to animal / children care and father / children conditions. 
Table 2.

Figurative B-terms in advertisement $A^{22}$

\begin{tabular}{|l|c|c|c|c|c|c|c|c|}
\hline Advertisement A & $\mathrm{C}^{2}$ & $\mathrm{~S}^{3}$ & $\mathrm{I}^{4}$ & $\mathrm{~A}^{5}$ & $\mathrm{~T}^{6}$ & $\mathrm{P}^{7}$ & $\mathrm{E}^{8}$ & $\mathrm{R}^{9}$ \\
\hline Bomb/weapon/grenade & 23 & 4 & 17 & 10 & 30 & 3 & & 10 \\
\hline Germs/bacterias & - & 20 & 4 & - & - & 13 & 8 & 5 \\
\hline Health & 8 & 6 & 9 & 18 & - & - & 23 & - \\
\hline Pesticides & - & - & - & 2 & - & 14 & - & 15 \\
\hline
\end{tabular}

Table 2.1

Figurative B-terms in advertisement B

\begin{tabular}{|l|c|c|c|c|c|c|c|c|}
\hline Advertisement B & C & S & I & A & T & P & E & R \\
\hline Animal care & 24 & 12 & 4 & & 6 & 9 & 6 & 4 \\
\hline Children care & 6 & 9 & 26 & 30 & 24 & 21 & 18 & 26 \\
\hline Neutral & - & 9 & - & - & - & - & 6 & - \\
\hline
\end{tabular}

Table 2.2

Figurative B-terms in advertisement C

\begin{tabular}{|l|c|c|c|c|c|c|c|c|}
\hline Advertisement C & C & S & I & A & T & P & E & R \\
\hline Father conditions & 3 & 15 & 23 & 5 & 15 & 4 & - & - \\
\hline $\begin{array}{l}\text { Children } \\
\text { conditions }\end{array}$ & 27 & 2 & 7 & 25 & 15 & 26 & 26 & 22 \\
\hline Neutral & - & 13 & - & - & - & - & 4 & 8 \\
\hline
\end{tabular}

The degree of aggressivity is shown in terms of how the three multimodal metaphors are considered by the participants: that is, as the most or the least aggressive advertisements presented in Table 3, Table 3.1 and 3.2. The following tables show the number of participants classified by both their language backgrounds and the reactions that these multimodal metaphors

${ }^{22}$ Notes: the labels used for the language backgrounds are the following: ${ }^{2}$ Chinese; ${ }^{3}$ Spanish; ${ }^{4}$ Italian; ${ }^{5}$ Arabic; ${ }^{6}$ Turkish; ${ }^{7}$ Polish; ${ }^{8}$ English; ${ }^{9}$ Romanian. 
incite. These reactions are rated as the most and the least aggressive ones in the sense that the latter term refers to those adverts which are regarded as more inoffensive, while the former refers to those adverts considered as more insensitive and offensive.

Table 3.

Degree of aggressivity in advertisement A

\begin{tabular}{|l|c|c|c|c|c|c|c|c|}
\hline Advertisement A & C & S & I & A & T & P & E & R \\
\hline Most aggressive & - & - & - & - & - & - & 4 & - \\
\hline Least aggressive & 18 & 20 & - & 15 & 15 & 8 & 11 & 15 \\
\hline
\end{tabular}

Table 3.1

Degree of aggressivity in advertisement B

\begin{tabular}{|l|c|c|c|c|c|c|c|c|}
\hline Advertisement B & C & S & I & A & T & P & E & R \\
\hline Most aggressive & 5 & 4 & 15 & 15 & - & 18 & 11 & 15 \\
\hline Least aggressive & - & 2 & - & - & - & - & - & - \\
\hline
\end{tabular}

Table 3.2

Degree of aggressivity in advertisement $C$

\begin{tabular}{|l|c|c|c|c|c|c|c|c|}
\hline Advertisement C & C & S & I & A & T & P & E & R \\
\hline Most aggressive & 15 & 7 & - & - & - & - & - & 3 \\
\hline Least aggressive & - & - & 15 & - & 15 & 4 & 4 & - \\
\hline
\end{tabular}

The sample comprises the responses from 240 participants who represented eight language backgrounds: 30 Arabic, 30 Chinese, 30 Romanian, 30 Spanish, 30 Polish, 30 Italian, 30 British and 30 Turkish. Most of the participants were university students who had a high level of English given that many of them were students in English philology or English linguistics; or they had lived in an English-speaking country. These participants ranged in age from 22 to 24 having just graduated from college (BA) and finding themselves at a postgraduate level of studies. The reasons for approaching this type of tertiary students were twofold as it was assumed that these students were highly trained and proficiently skilled in the English language and upheld a sense of 
professionalism and integrity in their responses. And secondly, the majority of these respondents were knowledgeable of the subject dealt with in this study.

\section{Instruments}

This study used a questionnaire which consisted of three multimodal metaphors and 8 questions; these multimodal metaphors related to current topics, such as war, religion and habits. The first variable included regarded foreign language and subject knowledge in the sense that these tertiary students have approximately the same knowledge of the language and of the subject under scrutiny. The second variable referred to the intention purported in the questionnaire, that is, the participants had open questions as a way for them to show their interpretations and beliefs freely for each of the multimodal metaphors. Close questions were avoided given that participants would have been more limited in their responses and, thus, the results could have been biased. It should be noted that some of the answers provided by the participants were too broad so that they had to be re-contacted for further clarifications about the responses given.

\section{Procedure}

Tertiary students from eight different language backgrounds were invited in person through online forums and also through friend networking inasmuch as many of my colleagues and friends shared the questionnaire with other participants in order to compile a larger sample in this study. By responding to a questionnaire, participants gave permission for the investigator to use information only for research purposes. The questionnaires were analyzed and a corpus was created according to the answers provided and, thus, some categories were established for implementing a comparison. In an attempt to make each participant feel as comfortable as possible, the questionnaires were anonymous. At the end of the data collection period, some participants were allowed to present more details of some of the answers provided since they varied in terms of length and interpretation. In addition, not only were participants allowed to provide details in the questionnaire, but also they were queried in person and online so as to have more information about their 
personal and cultural experiences and, thus, undergoing a more accurate approach in the analysis. For the analysis of these sub-corpora, the following procedures were used: on the one hand, a quantitative research method was followed as I attempted to calculate frequencies presented in graphs and, on the other hand, a qualitative method was used through an interpretive approach as to make sense of how different participants answered each of the questions.

\section{Results and discussion}

\section{Presentation: background and summary of results}

The principal findings of this paper reveal that the advertisements studied are all very rich in multimodal metaphors which seem to be mainly used to counter the effects that these metaphors provoke in the participants under study, namely, the reactions and interpretations triggered. These advertisements appear to have strongly influenced the behaviour of the participants in the way the message is construed. These types of multimodal metaphors are nowadays striving to raise awareness rather than to promote or to buy a product - which is achieved through negative advertising in order to have an impact on viewers and change their deportment. However, although the data examined mostly share the general aim of changing the behaviour of viewers through the means of the use of rather negative advertisements, important variations may be found in terms of a particular focus on the target audiences' personal and cultural experiences influencing the way they interpret and react to the metaphors.

As mentioned in the method section, this study consisted of the analysis of the interpretation of three multimodal metaphors by 240 participants from 8 different language backgrounds. The results are summarized in tables and graphs, in which the data retrieved from the corpus is shown, along with the interpretations of each of the multimodal metaphors.

Firstly, the variables selected are described in Table 4 below. These variables were chosen according to the answers provided by the participants 
given that participants had a tendency to construe the figurative B-term differently.

Table 4.

Figurative B-terms in the three multimodal advertisements

\begin{tabular}{|l|l|l|}
\hline Advert A & Advert B & Advert C \\
\hline Bomb/weapon/grenade & Animal care/tired & Father conditions/cancer \\
\hline Germs/bacterias & Children care/poverty & Children conditions/pity \\
\hline Health & Neutral & Neutral \\
\hline Pesticides & - & - \\
\hline
\end{tabular}

\section{In-depth analysis of the interpretations of the figurative B-term}

\section{Advertisement A}

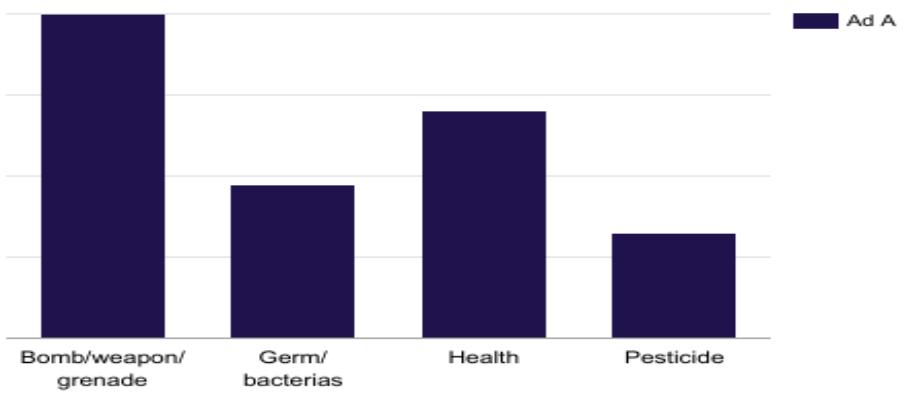

Fig. 1. Frequencies of the interpretations of the figurative B-terms in advertisement $A$

The figure shows how each of the 240 participants interpreted the advertisement $A$ (see in Appendix). In this ad there are four different ways of conceptualizing the figurative B term: a bomb / weapon / grenade, germs / bacteria, health and pesticide. As may be seen in graph 1 , the results are given in percentages.

These results highlight that $40 \%$ of the participants conceptualize advertisement A as a bomb / weapon / grenade. For instance, some Chinese 
participants conceptualize the concept of a tomato is a weapon and a tomato is a bomb. Similarly, Turkish participants construed the concept of the tomato as a bomb, but in this case the tomato is interpreted as connected with death owing to the fact that bombs/weapons/grenades are frequent and present in their culture and, therefore, it can be concluded that for this reason most of these participants give more importance to military action. On the other hand, $19 \%$ describe it as germs/bacteria, $28 \%$ as health and $13 \%$ as pesticides; for example, some Spanish and Polish participants think along the following lines: germs are a bomb, germs are a great danger and pesticides can kill you. It should be noted that these participants assert that they have a farming background and hence the figurative $B$-term that they perceive is bound to the dangers found in farms, namely, germs and pesticides. Others give more priority to health issues, as in the case of Arab participants who show more concern about getting fat as e.g. obesity is dangerous. These participants contended that obesity has been a present disorder in their lives at some period and that is why some apprehension is manifested in the responses given showing reluctance to experience it again.

These interpretations are related to each of the participant's experiences. As George Lakoff and Mark Johnson (1980, p. 57) argue: experience is cultural, so that we experience our "world" in such a way that our culture is already present in the very experience itself.

\section{Advertisement B}

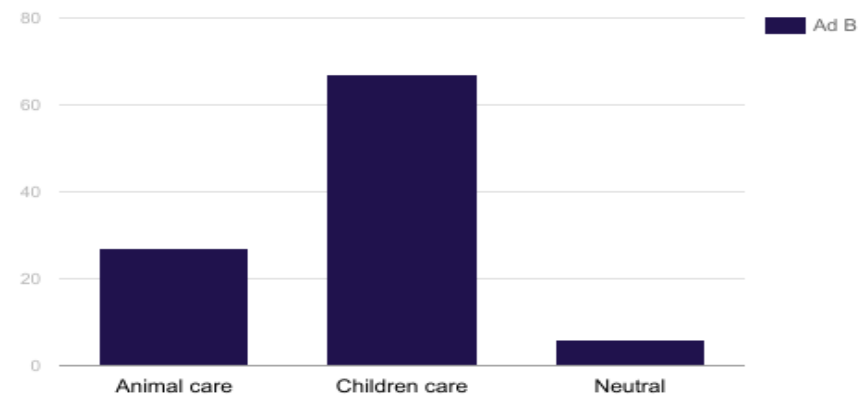

Fig. 1.1. Frequencies of the interpretations of the figurative B-terms in advertisement B 
The figure depicts the way each of the participants interpret the figurative Bterms of the advertisement B (see in Appendix). This ad comprises three different interpretations including animal care, children care and neutral which means that the participant gives the same importance to both animal and children care.

The results reveal that in ad B 67\%, that is, more than half of the participants, empathize with children rather than with animals, as in the case of the pig. For instance, Polish participants associate the new-born babies with poverty and vulnerability, others like English and Arab participants -- with stop hunger and starvation. This idea of social responsibility for children, who are considered as harmless creatures, is almost global and causes the same feeling of solidarity among different cultures. In contrast to the $27 \%$ of the participants, Italian respondents feel more empathy for the pig than for the children stating e.g. tired pig is a helper and children are being helped by this poor pig. It is also interesting to note that nearly $90 \%$ of the Chinese participants represent the pig as the mother of the children. These participants seem to show preference for the pig asserting that the pig has a more humane gesture for the children given that it is saving and protecting these hungry kids amicably.

It is also worth noting the $6 \%$ of the participants who keep neutral, for instance, Spaniards, think that babies are our future as the animals we feed on, a tired pig can feed even poor human babies, a tired pig is nursing 8 poor children, or dying children are helped by a poor pig. These examples present the pig and the children with the same degree of importance either through the use of comparatives of equality or attributing positive characteristics to both the pig and the children and, therefore, the participants empathize with the poor dirty children and the pig that is considered as charitable and as a rescuer who is taking care of the kids - something that humans lack. It is clear that so far experience and culture are two interwoven domains. As Forceville (2009, Introduction, p. 2) indicates, the interpretation of a metaphor tends to both reflect and influence the values and ways of thinking of a culture or society. The signification and appreciation of a metaphor are hence very likely to vary depending on viewers. 


\section{Advertisement C}

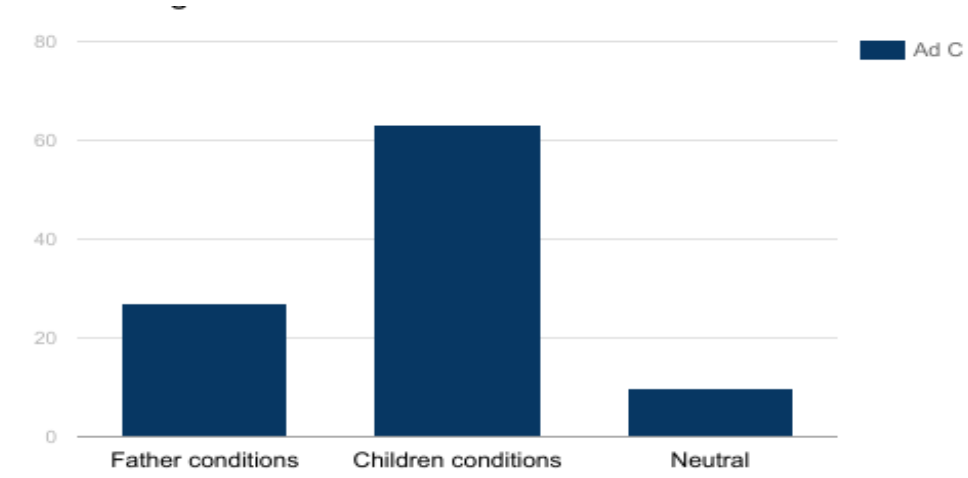

Fig. 1.2. Frequencies of the interpretations of the figurative Bterms in advertisement $C$

As shown in ad C (see in Appendix), some participants give priority to father conditions, while others to children; still others prefer to keep neutral given that these participants give the same priority to both father and children conditions.

The conditions of the children are regarded as important for $63 \%$ of the participants in contrast to ad B where children encompass $67 \%$. This difference between the interpretations of ad $B$ and ad $C$ regarding children may be caused by the fact that in ad B children are dirty and fed by an animal, whereas in ad $\mathrm{C}$ the picture is, according to some participants, more quotidian and frequent. Some Chinese, Polish and English participants conceptualize the idea of smoking and not giving money to the child as gross, for instance, cigarettes represent domestic violence, bad habits have serious consequences for your family, smoking is a waste of money or think of future generations. In this case, these participants feel compassion for the child in the sense that the father prefers wasting both his time and money on other things rather than spending time and giving money to the child. In contrast, $27 \%$ empathize with the father and this may be the consequence of the fact that they either mirror themselves in the ad or they have directly suffered from smoking; for example, some Turkish and Italian participants consider smoking dangerous for the health of the father up to the point of connecting the notion of smoking with death. Most of these participants relate this addiction to death given that 
nicotine dependence has been present in their lives and, therefore, these respondents are conscious of the consequences that smoking brings. Similarly, Arab participants consider smoking as something coarse, which seems to be a result of their cultural and societal background.

In contrast, $10 \%$ keep neutral, as for instance, Spanish participants think of smoking as something regular in their daily life and, therefore, as something quotidian, even contemplating the habit of smoking and not giving money to the child as a common situation. Most of these participants affirmed that they currently smoke, thus, these different interpretations are due to personal experiences, that is to say, each participant interprets the metaphors in different ways depending not only on their cultural background but also on their personal daily life. As for Gibbs (1994, p.435), the way we interpret metaphors may depend on our experiences and cultural background. Even a member of the same community may interpret their surrounding differently from the others.

\section{Degree of aggressivity}

Ad $A=\operatorname{Ad} B=\operatorname{Ad} C$

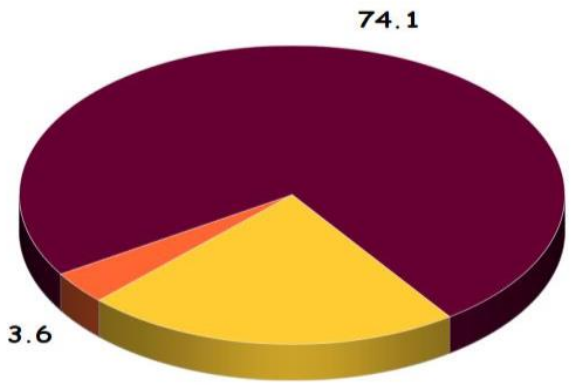

22. 3

Fig. 2. Degree of aggressivity in the three multimodal metaphors

As can be seen from Figure 2, the degree of aggressivity varies in each of the three multimodal metaphors. Ad B is regarded as the most aggressive one by more than half of the participants with $74.1 \%$ in contrast to the other two ads: most of the participants react negatively for the reason that this ad involves 
dirty children being fed by a pig. For example, Arab participants consider this multimodal metaphor as dirty and this occurs because of their cultural influence regarding the pig as a dingy and forbidden animal the babies are on the ground dirty and abandoned, serious danger for our children, the presence of children near a dead animal, or pig is a filthy animal and babies are touching it with their mouths. In contrast, the least aggressive multimodal metaphor is ad $A$ which constitutes $3.6 \%$ of the responses, these participants accounted for this ad as something common and quotidian in terms of that everybody should clean and wash vegetables before eating; others also consider that in their society a vegetable is not likely to be a bomb in terms of killing someone. In other words, it is considered as a hyperbole. For instance, food hygiene is a hot topic of public concern - it is common, tomato is a popular vegetable. Similarly, others interpret this as the least aggressive metaphor because of the fact that this image does not involve children in comparison to the other two multimodal metaphors since ad $A$ is the one which is the easiest to be solved in comparison to the others and ad $A$ does not affect children. Ad A is regarded as the most aggressive one for a small percentage of the participants as in the case of both vegans veggies are our daily diet and tomatoes are common there and Turkish participants, on account of the fact that this image conveys the idea of bombing. Ad C encompasses $22.3 \%$ of aggressivity mainly for Chinese participants who consider the idea of smoking as domestic violence and not a harmonious environment in the family. That is to say, for Chinese people the family plays an important role in their values, if the father spends money on tobacco than giving his child pocket money means that he is not a good father. However, some Spanish participants regarded this ad as the most aggressive one for two different reasons; firstly, smoking has been an addiction in their lives for a long-time suffering or life-long impairments; and secondly, some of these participants' relatives have also suffered the effects and consequences of smoking, such as lung cancer.

\section{Conclusion}

This paper has aimed at analysing how speakers from different language backgrounds interpret multimodal metaphors in three different advertisements. The adverts presented to the audience had the purpose of 
making a social impact of changing some behaviour and not of buying a product. Following Lakoff and Johnson's (1980) and Forceville's (1996, 2009) approaches, it has been sought to demonstrate that a cross-cultural approach could cast light on how these different speakers representing different cultures conceptualized the behavioural multimodal metaphors. It has been generally proved that while the three multimodal metaphors were the same, the reactions and interpretations were different; and this seems to be due to the audience's particular experiences and cross-cultural differences. Whereas the advertisements $B$ and $C$ have elicited a similar conceptualization of children since most of the participants gave priority and had a tendency to show empathy towards them, advertisement B was given more relevance, and this happened because of the way these children are represented, that is, as dirty and hungry kids. As it seems to be, this reaction could be related to the importance given to children's safety and care in our society. This increasing concern could be connected to the current situation in our society and the authority that social media has to influence the behaviour of the audience. However, the data analyzed from advertisement $A$ has revealed that participants' reactions do not vary as drastically as in the other two adverts given that this advert only evokes the idea of washing vegetables before eating for having a healthy life which is regarded as something quotidian that all of us should do. It should be furthermore noted that in each of the multimodal advertisements, even participants who belonged to the same community had a different view in the way they interpreted the ads, that is to say, not only the cultural background but also personal experiences and preferences are influential on the way people react to adverts.

Therefore, the analysis undertaken in this paper has revealed that significant correlations existed among the participants but also disparities in the way they reacted and interpreted the advertisements. In other words, while the three multimodal metaphors are the same, significant differences appear in terms of targeted audience, focus of conceptualization, individual experiences, and cross-cultural connotations. Although this research also involves important limitations since many of the answers provided by the participants were too general and open to subjective interpretations, respondents were re-contacted and required further clarifications. In addition, 
it would have been appropriate to have a more extended corpus so as to reach greater generalisations.

Nevertheless, the results could be taken as a basis to develop further similar studies on multimodal discourse. A promising line of study would be to examine, in more detail, if the present suggestions could be applied to other types of advertisements, that is, adverts that have another purpose than eliciting a behavioural change - and if this could entail similar reactions and cross-cultural and interpretive differences.

\section{References}

Bounegru, L., \& Forceville, C. (2011): Metaphors in editorial cartoons representing the global financial crisis. Journal of Visual Communication, 10, 209-229.

Carroll, N. (1994). Visual Metapho'. In J. Hintikka (ed.), Aspects of Metaphor (pp. 189-218). Dordrecht: Kluwer.

Cook, G. (2001). The Discourse of Advertising ( $2^{\text {nd }}$ ed.). Routledge.

Croft, W. (1993). The Role of Domains in the Interpretation of Metaphors and Metonymies, Cognitive Linguistics, 4, 335-370.

Dirven, R. (2009). Metonymy and metaphor: Different mental strategies of conceptualization. In C. Forceville, \& E. Urios-Aparisi (eds.), Multimodal Metaphor (pp. 19-42). Berlin: Mouton de Gruyter.

Esposito, J. A. (2011). Critical approach to the analysis of advertisements. The Linguistics Journal, 5(1), 197-219.

Forceville, C. (1994). Pictorial Metaphor in Advertisements. Metaphor and Symbolic Activity, 9(1), 1-29.

Forceville, C. (1996). Pictorial Metaphor in Advertising. New York: Routledge.

Forceville, C. (2002a). Further thoughts on delimitating pictorial metaphor. Theoria et Historia Scientiarum, 6, 213-27.

Forceville, C. (2006). Non - verbal and multimodal metaphor in a cognitivist framework: Agendas for research. In G. Kristiansen, M. Achard, R. Dirven, \& F. Ruiz de Mendoza (ed.), Cognitive Linguistics: Current Applications and Future Perspectives (pp. 379-402). Berlin and New York: Mouton de Gruyter. 
Forceville, C. (2008). Metaphor in Pictures and Multimodal Representations. In R. Gibbs (ed.), The Cambridge Handbook of Metaphor and thought (pp. 462-482). New York: Cambridge University.

Forceville, C. (2009). Non-verbal and multimodal metaphor in a cognitivist framework: Agendas for research. In C. Forceville \& E. Urios-Aparisi (eds.), Multimodal Metaphor (pp. 19-42). Berlin: Mouton de Gruyter.

Forceville, C. \& Urios-Aparisi, E. (2009). Introduction. In C. J. Forceville \& E. Urios-Aparisi (ed.), Applications of Cognitive Linguistics. Multimodal Metaphor (pp. 3-17). Berlin: Mouton de Gruyter.

Gibbs, R. (1994). The Poetics of the Mind: Figurative Thought, Language, and Understanding. Cambridge: Cambridge University Press.

Gibbs, R. W. (1999). Taking Metaphor out of Our Heads and Putting it into the Cultural World. In R. Gibbs and G. Steen, Metaphor in Cognitive Linguistics (pp. 145-166). Amsterdam/Philadelphia: John Benjamins.

Kövecses, Z. (2005). Metaphor in Culture: Universality and Variation. Cambridge: Cambridge University Press.

Lakoff, G. (1991). Metaphor and War: The Metaphor System Used to justify War in the Gulf. Distributed via electronic bulletin boards. Reprinted in B. Hallet (ed.), Engulfed in War: Just War and the Persian Gulf (pp. 95111). Honolulu: Matsunaga Institute for Peace.

Lakoff, G. (1993). The Contemporary Theory of Metaphor. In A. Ortony (ed.), Metaphor and Thought (pp. 202-251). Cambridge: Cambridge University Press.

Lakoff, G. \& Mark, J. (1980). Metaphors we live by. Chicago: University of Chicago Press.

Lakoff, G. \& Turner, M. (1989). More Than Cool Reason: A Field Guide to Poetic Metaphor. Chicago: Univ. of Chicago Press.

Langacker, R. W. (1987). Foundations of Cognitive Grammar: Theoretical Prerequisites. Stanford, CA: Stanford University Press.

Shore, B. (1996). Culture in Mind: Cognition, Culture, and the Problem of Meaning. New York/Oxford: Oxford University Press. 


\section{Online Courses and Resources}

Forceville, C. (2009). A Course in Pictorial and Multimodal Metaphor.

Introduction. Retrieved from

http://www.chass.utoronto.ca/epc/srb/cyber/cforcevilleout.pdf

Lecture 1. Retrieved from

http://www.chass.utoronto.ca/epc/srb/cyber/cforceville1.pdf

Lecture 2. Retrieved from

http://www.chass.utoronto.ca/epc/srb/cyber/cforceville2.pdf

Lecture 3. Retrieved from

http://www.chass.utoronto.ca/epc/srb/cyber/cforceville3.pdf

Lecture 4. Retrieved from

http://www.chass.utoronto.ca/epc/srb/cyber/cforceville4.pdf

\section{Appendixes}

\section{Appendix 1: questionnaire}

\section{The Questionnaire}

This questionnaire is only used for personal research purpose and will be kept strictly confidential! Please write down the answers according to your own understanding. Thank you very much for your cooperation!

Directions: In the following questionnaire you will be presented with 8 questions. Please answer all of them briefly within 20 minutes. If you come across any difficult words, you may look them up in the dictionary, but do not discuss with others.

1. Sex: $\square$ Male $\square$ Female

2. Place of birth:

3. Have you lived in and English-speaking country $\square$ YES $\quad$ NO

If so, specify the country:

4. Native speakers --- English is my first language $\square$ OTHERWISE, specify your English level according to the CEFR (Common European Framework of Reference)

$\square$ Beginners (A1-A2) $\square$ Intermediate (B1-B2) $\square$ Advanced (C1-C2)

5. What is the highest level of education you have completed? (i.e. did not attend school, 1st grade, 2d school, graduated from high school, graduated from college...)

If you have university studies, please specify which one(s) 


\section{Image analysis.}

6. Define the metaphor you can distinguish in each of the cases (i.e woods are lungs)

Image A:

Image B:

Image C:

7. What can you see in these adverts? (brief description) i.e a woman, a cigarette shaping an object...

Image A:

Image B:

Image C:

8. According to your cultural background order each of the images in the following form. In the first position the less aggressive image and in the last the most aggressive one.

10

$2^{\circ}$

30

Why do you consider the images chosen as the most and less aggressive ones?

\section{Appendix 2: Adverts}

\section{Advertisement A.}

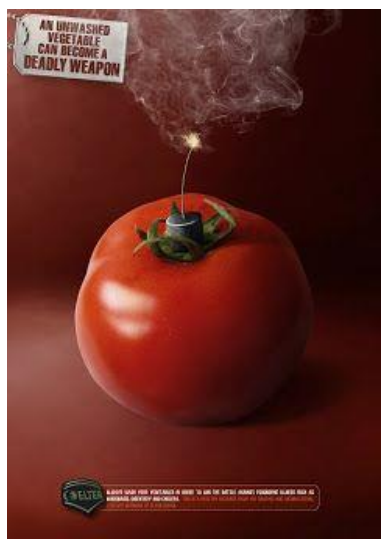

Advertisement B.

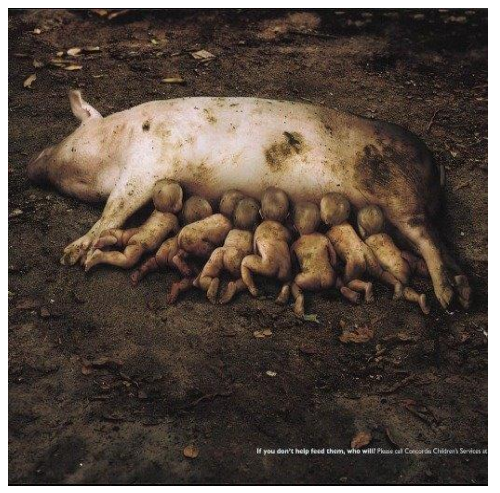

Text: "if you don't help feed them, who will? Please call Concordia Children's Services at XXX
Advertisement C.

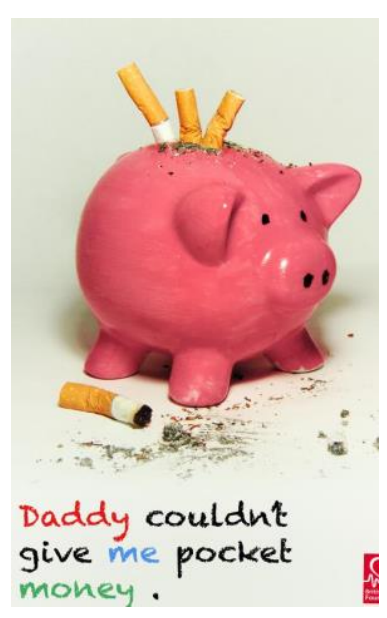




\section{John Fredy Gil Bonilla}

Madrido Komplutensès universitetas, Ispanija; jhongil@ucm.es

\section{MULTIMODALINĖS METAFOROS IR REKLAMA: TARPKULTŪRINIS MULTIMODALINIU METAFORU VARTOJIMO PALYGINIMAS}

Santrauka. Pagrindinis šio straipsnio tikslas - išanalizuoti kultūros sąsajas su skirtingu kalbu žiūrovy multimodaliniu metaforu suvokimu ir interpretacija. Dèl šios priežasties metaforos ir kultūros sąveika yra esminis šio tyrimo aspektas. Remiantis Lakoff ir Johnson (1980) bei Forceville $(1996,2009)$ sukurtais metodais, šiame straipsnyje yra nagrinèjama, kaip lyginamasis tyrimas, atliktas iš tarpkultūrinès perspektyvos, gali atskleisti kultūros daroma itaką ir pokyčius žiūrovy interpretacijai ir reakcijai. Tyrime dalyvavo 240 tyrimo dalyviu, atstovaujančiu 8 skirtingomis kalbomis kalbančias šalis. Tyrimo subjektams buvo pateikta anketa, kuria sudare trys multimodalinès metaforos ir 8 klausimai. Pagrindiniai tyrimo klausimai: (1) Kuris perkeltine prasme vartojamas B terminas yra skirtingu kultūru konceptualizuojamas multimodalinèje metaforoje? (2) Kiek, tyrimo dalyviu požiūriu, šios multimodalinės metaforos yra agresyvios? Remiantis tyrimo rezultatais galima daryti išvada, kad ne tik kultūrinis pagrindas, bet ir asmeniniai skirtumai daro itaka respondentu multimodaliniu metaforu interpretacijai. Subjektu atsakymuose nustatytas reakcijas salygoja ìvairūs veiksniai: religija, asmeninè ir socialinè patirtis, isitikinimai, ir kita.

Pagrindinès sąvokos: multimodalumas; metaforos; reklama; tarpkultūriniai skirtumai; konceptualizacija. 